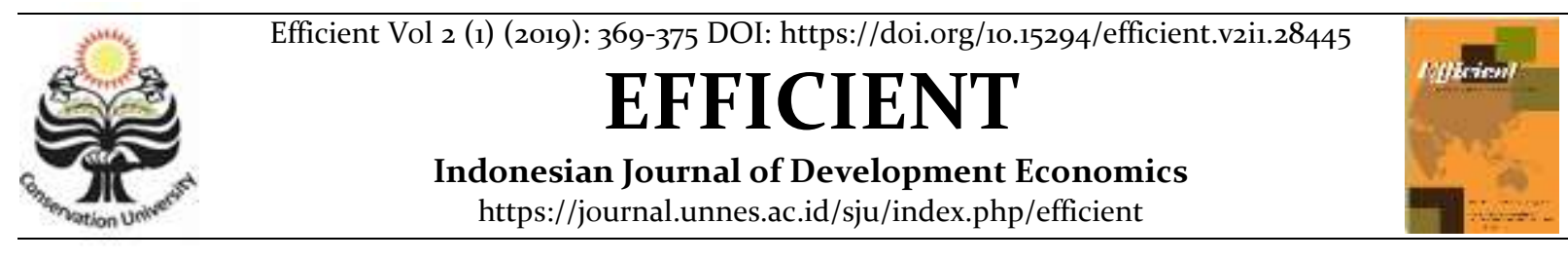

\title{
Factors that Influence the Productivity of Green Bean Farming in Demak District
}

\author{
Ufi Muflihah ${ }^{\bowtie}$ \\ Jurusan Ekonomi Pembangunan, Fakultas Ekonomi, Universitas Negeri Semarang \\ Permalink/DOI: https://doi.org/10.15294/efficient.v2i1.28445
}

Received: July 2018 ; Accepted: October 2018 ; Published: January 2019

\begin{abstract}
Demak regency is the center of green bean however, the productivity of green beans in Demak Regency has decreased during 2009-2016. The aims of study is determine the effect of land area, seeds, labor, fertilizer, pesticides on the productivity of green beans. This type of research is quantitative research. The data used was primary data. The population in this study is that farmers in Demak Regency with samples of mung bean farmers in Demak Regency totaled 10o people. The analytical method uses descriptive analysis and multiple linear regression analysis with the Ordinary Least Square (OLS) method through the Cobb-Douglas production function model. From the results of this study showed that area of land, fertilizer, pecticides have a significant positive effect on the productivity of green beans which every increase in labor will reduce productivity of green beans, while the seeds have no significant positive effect on the productivity of green beans which increase in the number of seeds does not affect the productivity of green beans. The suggestion of this reserach are that the unused area further improved itd use, the seeds are planted with better planting methods that will is not easily damaged by the weather, there should be a division of labor in green bean farming so that the workers can work productively, the intensity of spraying fertilizers can be improved to increase green bean production, the intensity of spraying of pesticides can be increased to minimize the harvest of crops.
\end{abstract}

Keywords: Land, seed, labor, fertilizer, pesticide

\begin{abstract}
Abstrak
Kabupaten Demak adalah pusat kacang hijau, namun produktivitas kacang hijau di Kabupaten Demak mengalami penurunan selama 2009-2016. Tujuan penelitian adalah mengetahui pengaruh luas lahan, benih, tenaga kerja, pupuk, pestisida terhadap produktivitas kacang hijau. Jenis penelitian ini adalah penelitian kuantitatif. Data yang digunakan adalah data primer. Populasi dalam penelitian ini adalah petani di Kabupaten Demak dengan sampel petani kacang hijau di Kabupaten Demak berjumlah 100 orang. Metode analisis menggunakan analisis deskriptif dan analisis regresi linier berganda dengan metode Ordinary Least Square (OLS) melalui model fungsi produksi Cobb-Douglas. Dari hasil penelitian ini menunjukkan bahwa luas lahan, pupuk, pektisida berpengaruh positif signifikan terhadap produktivitas kacang hijau dimana setiap peningkatan tenaga kerja akan menurunkan produktivitas kacang hijau, sedangkan benih tidak berpengaruh positif signifikan terhadap produktivitas tanaman hijau. kacang hijau yang meningkatkan jumlah biji tidak mempengaruhi produktivitas kacang hijau. Saran dari penelitian ini adalah agar daerah yang tidak digunakan semakin ditingkatkan penggunaannya, benih ditanam dengan metode penanaman yang lebih baik sehingga tidak mudah rusak oleh cuaca, harus ada pembagian kerja dalam pertanian kacang hijau sehingga para pekerja dapat bekerja Secara produktif, intensitas penyemprotan pupuk dapat ditingkatkan untuk meningkatkan produksi kacang hijau, intensitas penyemprotan pestisida dapat ditingkatkan untuk meminimalkan panen tanaman
\end{abstract}

Kata Kunci: Tanah, benih, tenaga kerja, pupuk, pestisida

How to Cite: Muflihah, U. (2019). Factors that Influence the Productivity of Green Bean Farming in Demak District. EFFICIENT Indonesian Journal of Development Economics, 2(1), 369-375. https://doi.org/10.15294/efficient.v2i1.28445

(c) 2019 Semarang State University. All rights reserved

\footnotetext{
Alamat Korespondensi :

Alamat: Gedung L2 Lantai 2 FE Unnes

Kampus Sekaran, Gunungpati, Semarang, 50229

E-mail : ufimuflihah1996@gmail.com
}

ISSN 2655-6197 


\section{INTRODUCTION}

Food is an essential and strategic commodity for Indonesian people as food is human basic need that should be fulfilled by the government together with the community as mandated by Law No. 7 of 1996 on food (Prajanti, SDW; et al, 2018). Indonesia has variety of food resources to meet domestic basic needs but still rely on rice as a staple food commodity, However sustainable food diversification efforts are important to do with the implementation of food diversification policies through the utilization of local food potential in each region (Kusrini, et al., 2017)

Indonesia has local food potential with a total of 77 types of carbohydrate-containing food sources, namely 26 types of beans, 389 fruits, 228 kinds of fruit drinks, and 110 types of spices (Kusrini, et al., 2017).

Based on the existing local food potential to realize local food diversification, non-rice food resources are green beans through increased productivity by optimizing the development of green bean production centers with efficient use of inputs so as to increase high productivity (Ministry of Agriculture, 2012).

Central Java Province is an area that has the potential to develop local food diversification. According to Trustinah, dkk., (2014) the potential of mung beans in Central Java have harvest area of more than 10,00o ha with the highest production contribution of $34.1 \%$ of the total national production.

The level of productivity of green beans in Central Java cannot be separated from the green bean production area, Demak Regency. However, the productivity of green beans in Demak Regency since 2009-2016 have fluctuating growth but tended to have a decline where the increase in productivity is smaller compared to the decrease in productivity.

The decrease in total productivity is 4.8 kuntial per hectare while the total increase was 3.8 quintals per hectare Demak Regency Central Statistics Agency, 2012 \& 2017). If the level of productivity is still below the potential productivity will have an impact on the production of area unity to be low so that the loss of economic value for both farmers and the state.

Pamorina (2013) productivity is the ratio of total output to inputs used in production. In this study, the inputs used include land area, seed, labor, fertilizer and pesticide. Therefore, this study aims to determine the effect of land area, seed, labor, fertilizer, pesticide on the productivity of green beans.

\section{RESEARCH METHOD}

This study used quantitative approach because it uses green bean productivity data in Demak Regency. The data used in this study primary data obtained directly in the area of the study area.

Pamoriana (2013) population is the whole research subject, while the sample is part of the population studied. The population are farmers in Demak Regency, amounting to 158.33 people (Demak Regency Central Statistics Agency, 2012 \& 2017).

The sample in this study is a mung bean farmer in Demak Regency which is calculated using the Slovin equation (Kurniawan, 2014).

$$
\mathrm{n}=\frac{\mathrm{N}}{1+\mathrm{N}(e)^{2}}
$$


So that a sample size of 100 samples of green bean farmers in Demak Regency was obtained. The sampling technique used stratified random sampling with proportional allocation due to peanut production green in Demak Regency is found in all areas of Demak Regency. The analytical method used in this study was descriptive analysis and multiple linear regression analysis using the Ordinary Least Square (OLS) method through the Cobb Douglas production function model. The form of the equation is as follows:

$$
\begin{aligned}
\operatorname{In}(\mathrm{Y})= & \operatorname{In}\left(\beta_{\mathrm{o}}\right)+\beta_{1} \operatorname{In}\left(\mathrm{X}_{1}\right)+\beta_{2} \operatorname{In}\left(\mathrm{X}_{2}\right)+\beta_{3} \operatorname{In}\left(\mathrm{X}_{3}\right)+ \\
& \beta_{4} \operatorname{In}\left(\mathrm{X}_{4}\right)+\beta_{5} \operatorname{In}\left(\mathrm{X}_{5}\right)+\varepsilon \ldots \ldots \ldots \ldots \ldots \ldots \ldots \ldots \ldots \ldots \ldots \ldots \ldots \ldots \ldots
\end{aligned}
$$

Information:

$\begin{array}{ll}\beta_{0} & =\text { Intersep } \\ \beta_{1,} \beta_{2,} \beta_{3,} \beta_{4,} \beta_{5} & =\text { Variable parameters } \\ \mathrm{Y} & =\text { GreenBeanProductifity } \\ \varepsilon & =\text { error term } \\ X_{1} & =\text { Land Area (Acres) } \\ X_{2} & =\text { Seeds (Kilogram) } \\ X_{3} & =\text { Labor (person) } \\ X_{4} & =\text { Fertilizer (Liter) } \\ X_{5} & =\text { Pesticides (Liter) }\end{array}$

\section{RESULT AND DISCUSSION}

This research area in Demak Regency is located at coordinates 6043'26"-7009'43" South Latitude and 110027'58"-110048'47" East Longitude. This analysis is used to determine the effect of land area variables $\left(\mathrm{X}_{1}\right)$, seeds $\left(\mathrm{X}_{2}\right)$, labor $\left(\mathrm{X}_{3}\right)$, fertilizer $\left(\mathrm{X}_{4}\right)$, pesticides $\left(\mathrm{X}_{5}\right)$ on the Based on Table 1 , can be obtained the cross section data regression equation as follows:

$$
\begin{aligned}
& \mathrm{LnY}=1.942857+0.604150 \text { Ln_ Land Area }+ \\
& \text { o.074145 Ln_Seed - } 1.123545 \\
& \text { Ln_Labor + } 0.184069 \text { Ln_Fertilizer + } \\
& \text { o.091667 Ln_Pesticide }
\end{aligned}
$$

Table 1. Result of Multiple Linear Regression Analysis

\begin{tabular}{ll}
\hline Variabel & Coeffesien \\
\hline C & 1.942857 \\
Ln_Land Area & 0.604150 \\
Ln_Seed & 0.074145 \\
Ln_Labor & -1.123545 \\
Ln_Fertilizer & 0.184069 \\
Ln_Pesticide & 0.091667 \\
\hline
\end{tabular}

Source: Processed the data primery, 2018

Based on the multiple linear regression equation above, it can be interpreted as follows: 1) Constant value $(C)=1.942857$ means that if all the independent variables are considered equal to $\mathrm{o}$ then the green bean productivity is $1.9 \%$; 2) The coefficient of land area $\left(\mathrm{X}_{1}\right)$ is 0.604150 which means that when the land area increases by $1 \%$ it will increase the productivity of green beans by $0.6 \%$ assuming the other independent variables boarding house (cateris paribus); 3) Seed coefficient value $\left(\mathrm{X}_{2}\right)$ is 0.074145 which means that when the seed.

Based on Table 2 it is known that the influence of independent variables (land area, seeds, labor, fertilizer, pesticides) on the multiple linear regression analysis using Eviews9 program. The following table 1 results of multiple linear regression analysis productivity has agreen beans by $0.07 \%$ increases by $1 \%$ it will incease the productivity independent variables are boarding house 
(cateris paribus); 4) The value of labor coefficient $\left(\mathrm{X}_{3}\right)$ is -1.123545 which means that when the labor increases by $1 \%$ it will decrease the productivity of green beans by $1.1 \%$ assuming other independent variables boarding house (cateris paribus); 5) Fertilizer coefficient value $\left(\mathrm{X}_{4}\right)$ of 0.184069 means that when fertilizer increases by $1 \%$ will increase the productivity of green beans by $0.2 \%$ assuming other independent variables boarding house (cateris paribus); 6) The value of pesticide coefficient $\left(\mathrm{X}_{5}\right)$ is 0.091667 which means that when pesticides increase by $1 \%$ it will increase the productivity of green beans by 0.09\% with assuming that other independent variables are boarding (ceteris paribus). dependent variable (productivity of green beans) partially.

Table 2. Result of Hypotheses Test with Partially Tes (Test t)

\begin{tabular}{llll}
\hline Variable & Coeffesien & Prob. & $\boldsymbol{\alpha}=\mathbf{5 \%}$ \\
\hline Ln_Land & 0,604150 & 0,000o & 0,05 \\
Area & & & \\
Ln_Seed & 0,074145 & 0,1243 & 0,05 \\
Ln_Labor & $-1,123545$ & 0,0000 & 0,05 \\
Ln_Fertilizer & 0,184069 & 0,0032 & 0,05 \\
Ln_Pesticide & 0,091667 & 0,0218 & 0,05 \\
\hline
\end{tabular}

Source: Processed the data primery, 2018

The land area of green bean probability value of $0.0000<0.05$ and has a coefficient of o.604150. This means, the land area has a significant effect on the productivity of green beans and is positively related to the productivity of green beans where each increase in land area of $1 \%$ increase the productivity of green beans by $0.6 \%$ assuming other independent variables are constant. So, the results are appropriate with hypothesis this study which states that the land area has a positive and significant influence on the productivity of green beans.

Seeds on the productivity of green beans have probability value of $0.1243>0.05$ and have coefficient of 0.074145 . This means, the seeds have no significant effect on the productivity of green beans and have positive relationship to the productivity of green beans where each $1 \%$ that seed increase will increasing the productivity of green beans by $0.1 \%$ assuming other independent variables are constant. So, the results are not approrite with hypothesis this study because of this research hypothesis states that seed have a positive and significant relationship to the productivity of green beans.

Labor on the productivity of green beans has probability value of $0.0000<0.05$ and has coefficient of -1.123545. This means, labor has significant effect on the productivity of green beans and has negative relationship to the productivity of green beans where each increase that labor by $1 \%$ will reducing the productivity of green beans by $1.1 \%$ with assuming other variables are constant. So, these results are not appropriate with the hypothesis of this study which states that the relationship of labor has positive and significant relationship to the productivity of green beans.

Fertilizer on green beans productivity probability value of $0.0032<0.05$ and has coefficient of 0.184069 . This means, the fertilizer has significant relationship to the productivity of green beans and has positive relationship where each fertilizer increase of $1 \%$ will increase the productivity of green beans by $0.2 \%$ assuming other independent variables are constant. So, these results are 
appropriate with the hypothesis of this study which states that fertilizer have positive relatioship and have a significant effect on the productivity of green beans.

Pesticides on the productivity of green beans have probability value of $0.0218<0.05$ and have coefficient of 0.091667 . This means that the variables of pesticides have significant effect on the productivity of green beans and have positive relationship to the productivity of green beans where each increase of pesticides by $1 \%$ will increasing the productivity of green beans by $0.1 \%$ assuming other independent variables are constant. So, these results are not appropriate with the hypothesis of this study which states that pesticide have negative relationship and have significant effect on the productivity of green beans.

Statistical $\mathrm{f}$ test was used to determine the effect of independent variables of land area, seeds, labor, fertilizer and pesticides together on the dependent variable productivity of green beans. Based on the results of the F test, those where stated that the independent variables of land area, seeds, labor, fertilizers and pesticides used together influence the dependent variable productivity of mung bean farming. This can be known by comparing the probability value (F-Statistics) of o.oooooo smaller than $\alpha=5 \%$. So, these are can be say positive and significant influence between land area, seeds, labor, fertilizer, pesticides together on the productivity of green beans.

The determination coefficient which adjusted for show the accuracy or suitability of the regression line. Based on the test results of the adjusted determination coefficient was showed the value of the adjusted coefficient of 0.780713 . There mean, the variation of green beans productivity are explains by the model of $78.07 \%$ and the remaine $21.93 \%$ is explain by other variables outside the model.

The classic assumption test is done to find out whether the estimation model meets econometric criteria, in a sense there is no serious deviation from the assumptions that must find out whether the estimation model

Based on Table 5, it can be seen that the free regression model of multicollinearity disorder shows that the main model does not have more than 0.85 , so this model is free from the problem of multicollinearity. There means, there are no partial correlation between one variable and another.

Heterocedasticity test is a condition in meets be met in the Ordinary Least Square (OLS) method. The classic assumptions that must be fulfills are normality test, multicollinearity test, heteredasticity test.

Normality test aims to see the effect of the significance of the independent variable on the dependent variable has residual which normal distribution. In this study, the normality test using the Jarque-Bera test or the Jarque-Bera (J-B)8 method. Based on the results of the normality test using the JarqueBera method shows a probability value of 0.907032 . This means, the probability value is $90.7 \%>\alpha=5 \%$, so the residual is normally distribut. So, the results of the $t$ test were carried out in this study would be declared valid. Multicollinearity test aims to exam there are linear relationship between independent variables in multiple regression or to bride between independent variables. The following table 5 results of multicollinearity test: 
Table 3. Results Of Multicollinearity Test

\begin{tabular}{ll}
\hline Variable & $\begin{array}{l}\text { Coeffesient } \\
\text { Partial Correlation }\end{array}$ \\
\hline Ln_Land Area & 0.009883 \\
Ln_Seed & 0.067325 \\
Ln_Labor & 0.540798 \\
Ln_Fertilizer & 0.007935 \\
Ln_Pesticide & 0.085917 \\
\hline
\end{tabular}

Source: Processed the data primery, 2018

Not constant for all independent variables or to which variants and errors are interfering see if there are variations of errors that are constant or identical. In this study, the method use to determine whether or not there is a heteroscedasticity problem is by using the Glejser method. The following table 6 results of heteroscedasticity test can be seen below:

Table 4. Results of Heteroscedasticity Test

\begin{tabular}{llll}
\hline F-statistic & 2.204692 & Prob. F(5,94) & 0.0602 \\
\hline $\begin{array}{l}\text { Obs*R- } \\
\text { squared }\end{array}$ & 10.49619 & $\begin{array}{l}\text { Prob. Chi- } \\
\text { Square(5) }\end{array}$ & 0.0623 \\
$\begin{array}{l}\text { Scaled } \\
\text { explained } \\
\text { SS }\end{array}$ & 10.43906 & $\begin{array}{l}\text { Prob. Chi- } \\
\text { Square(5) }\end{array}$ & 0.0637 \\
\hline
\end{tabular}

Source: Processed the data primery, 2018

Based on Table 6 it can be seen that the chi square probability value is $0.0623>0.05$ this mean, the regression model this study is free from heteroscedasticity problems. So, the regression model this study has error variation constant (fixed) or is called identical.

The results showed that the land area have positive and significant effect on the productivity of green beans in Demak District increase the productivity of green beans because the land in the Regency Demak has the characteristics of land not too dry and not too much water so it suitable for planting green beans and produce productivity that increase. Therefore, Demak Regency is the center of green bean production.

The results showed that the seed have positive and insignificant effect on the productivity of green beans in Demak Regency. The seeds which have positive and insignificant effect indicate that any additioning of seeds in green bean farming in Demak Regency have not been increasing the productivity of green beans because the seeds is plant can be damage by the weather even though, the number of seeds use is lot but does not necessarily result increase productivity of green beans.

The results showed that labor has negative and significant effect on the productivity of green beans. This means, any increase in labor reduce the productivity of green beans. This happens because of the continuous addition of labor while other inputs still reduce the output that is produced because the workers is less productive because the land This means used increasingly narrowly. therefore, there decrease in additional output reduce the productivity of green beans.

The results showed that fertilizer have positive and significant effect on the productivity of green beans. This means, every increase in the amount of fertilizer use increase the productivity of green beans because fertilizer is substance to fertilize plant so that can thrive so as to will increase the productivity of green beans after fertilization. The results showed that pesticides have positive and significant effect on the productivity of green beans. This means, there is increasing number of pesticide use, the less chance of contracting pests so that the productivity of green bean produce not 
decrease. On the contrary, if the number of pesticide use decreases the chance of contracting pests increase so that the productivity of green beans produced decrease and harm farmers because pests can make minimal yields of green beans.

\section{CONCLUSION}

Based on the results of data analysis and discussion of research conducted on green bean farmers in Demak Regency, it can be concluded that the land area has significant positive effect on the productivity of green bean, the seed do not has significant positive effect on the productivity of green bean, labor has significant negative effect on productivity of green bean, Fertilizer has significant positive effect on the productivity of green bean, Pesticides has significant positive effect on the productivity of green bean.

The suggestion from this research is that the use of unused land is better used in green bean farming, the seeds should be planted with better planting methods so that they are not easily damaged by the weather, there should be a division of tasks in mung bean farming so that the workers can work more productively, the intensity of fertilizer spraying should be increased so that the production of green beans increases, the intensity of pesticide spraying should be increased so that the minimum yield can increase.

\section{REFERENCES}

Demak Regency Central Statistics Agency, 2012 \& 2017. Demak in Figures, Demak: Demak Regency's Central Statistics Agency.

Demak Regency's Central Bureau of Statistics, 2012. Demak in Figures, Demak: Demak Regency's Central Statistics Agency.

I., Kusrini, N. \& Hidayat, R., 2017. Development Strategy of Local Food Diversification. Journal of Economics and Policy, 09, 10 (1), pp. 62-79.

Ministry of Agriculture, 2012. Road map for increasing production of peanuts \& green beans in 2010-2014. In: s.l.:Directorate General of the Ministry of Agriculture.

Kurniawan, A., 2014. Research Methods for Economics \& Business Theory, Business Research Concepts \& Practices (Equipped with Data Processing Calculations with IBM SPSS 22.0). Bandung: Alfabeta.

Pamorina, W., 2013. Analysis of Coffee Crop Productivity in Gemawang District, Temanggung Regency. Journal of Economic Development, 2 (1).

Trustinah, B. R., Prasetiaswati, N. \& Harnowo, D., 2014. Adoption of Superior Varieties of Green Beans at the Production Center. Food Crop Science and Technology, 9 (1).

Prajanti, SDW. Wilonoyudho, Saratri. Farid, Ahmadi. Oktavilia, Shanty. (2018). Integration of Agricultural Research Planning and Its Implementation to Improve Food Security Through Development of Agricultural Research Information System (SIPP). The Efficiency Analysis of Food Crop Commodities. ICE-BEES 2018 (International Conference on Economics, Business and Economic Education 2018) .Doi: 10.18502/kss.v3i10.3163. 